\title{
STRATEGI PENINGKATAN INDEKS PENDIDIKAN MELALUI ALOKASI BELANJA PEMERINTAH DAERAH BIDANG PENDIDIKAN DI PROVINSI
}

\author{
JAWA TIMUR
}

The Strategy for Increasing the Education Index by Allocating the Local Government Expenditure for Education in East Java Province

\author{
Roy Mahendra ${ }^{1}$, Anna Fariyanti ${ }^{2}$, A Faroby Falatehan ${ }^{2}$ \\ ${ }^{1}$ Badan Pengawasan Keuangan Dan Pembangunan Email: roymahendra10@gmail.com \\ ${ }^{2}$ Staff Pengajar Departemen Agribisnis, Fakultas Ekonomi dan Manajemen IPB. Email: a_fariyanti@yahoo.com, \\ Staff Pengajar Departemen Ekonomi Sumberdaya dan Lingkungan, Fakultas Ekonomi dan Manajemen IPB. \\ Email :f_falatehan@hotmail.com
}

\begin{abstract}
Education is an important investment to improve regional competitiveness in the future. One indicator of the successful development in education is the education index. The objectives of this study were (a) to identify the factors that influence the education index in the East Java province, (b) to formulate a strategy that can increase the index education in the East Java province. The data used in this study are secondary and primary types. The data was analyzed using multiple regression analysis of the panel data and Analytical Hierarchy Process (AHP) analysis. The results showed that factors that significantly affected the education index in East Java positively were these variables: the allocated local government spending in education, income per capita, junior high school enrollment rate, senior high school enrollment rate, and the student-teacher ratio in elementary schools. The first priority of strategy based on AHP to increase the education index of East Java is equal distribution in the quantity of educators.
\end{abstract}

\begin{abstract}
ABSTRAK
Pendidikan adalah investasi penting untuk meningkatkan daya saing daerah di masa yang akan datang. Salah satu indikator keberhasilan pada sektor pendidikan adalah indeks pendidikan. Tujuan dari kajian ini adalah (a) mengidentifikasi factor-faktor yang mempengaruhi indeks pendidikan di Provinsi Jawa Timur, (b) memformulasikan strategi untuk meningkatkan indeks pendidikan di Provinsi Jawa Timur. Data yang digunakan dalam kajian ini adalah data sekunder dan data primer. Analisis yang digunakan adalah analisis regresi berganda data panel dan Analytical Hierarchy Process $(A H P)$. Hasil analisis menunjukkan bahwa faktor-faktor yang secara signifikan dan positif mempengaruhi indeks pendidikan di Jawa Timur adalah: alokasi belanja pemerintah daerah bidang pendidikan, pendapatan per kapita, Angka Partisipasi Sekolah tingkat SMP, Angka Partisipasi Sekolah tingkat SMA, dan rasio murid-guru tingkat SD. Prioritas strategi pertama untuk meningkatkan indeks pendidikan di Jawa Timur berdasarkan analisis AHP yaitu pemerataan kuantitas tenaga pendidik.
\end{abstract}

\section{PENDAHULUAN}

Pendidikan adalah faktor penting yang berpengaruh terhadap kemajuan suatu daerah/ bangsa di masa yang akan datang. Di era persaingan bebas saat ini, pemerintah daerah harus mempersiapkan sumber daya manusia yang unggul agar daerahnya tidak tertinggal dengan daerah lain. Sejak tahun 2015, Indonesia harus menghadapi pasar bebas ASEAN yang lebih dikenal dengan Masyarakat Ekonomi ASEAN (MEA). Hanya daerah yang siap dan memiliki keunggulan kualitas sumber daya manusia yang mampu bertahan terhadap persaingan bebas. 
Pembukaan Undang-Undang Dasar 1945 juga menekankan arti pentingnya pendidikan bagi kemajuan bangsa. Pembukaan Undang-Undang Dasar 1945 menyatakan bahwa salah satu tujuan berdirinya bangsa Indonesia adalah memajukan kesejahteraan umum dan mencerdaskan kehidupan bangsa. Pembangunan di bidang pendidikan merupakan sebuah keharusan bagi pemerintah karena hal ini merupakan amanat dari pembukaan Undang-undang Dasar 1945. Pembangunan yang dilakukan oleh pemerintah dengan memanfaatkan segala sumber daya yang ada terutama melalui Anggaran Pendapatan dan Belanja Negara/ Daerah (APBN/D) juga ditujukan untuk mencapai tujuan tersebut.

Salah satu indikator keberhasilan pembangunan di bidang pendidikan yang dilakukan pemerintah baik di tingkat pusat maupun daerah adalah indeks pendidikan. Indeks pendidikan adalah komponen yang menyusun Indeks Pembangunan Manusia (IPM). Selain indeks pendidikan, komponen penyusun IPM adalah Indeks Kesehatan dan Indeks Pengeluaran. IPM lebih komprehensif dalam mengukur tingkat keberhasilan dari proses pembangunan yang dilaksanakan oleh pemerintah dibandingkan dengan indikator Pendapatan Domestik Bruto/ Pendapatan Domestik Regional Bruto (PDB/PDRB) yang hanya mencakup aspek ekonomi saja.

IPM melakukan pengukuran indeks atas dasar asumsi bahwa manusia yang berkualitas adalah manusia yang hidup sehat dan panjang umur, memiliki pendidikan dan kecakapan hidup yang berguna bagi kehidupan masyarakatnya, serta dapat mencapai standar hidup yang layak. Bahkan, sejarah mencatat bahwa negara yang menerapkan paradigma pembangunan berdimensi manusia telah mampu berkembang meskipun tidak memiliki kekayaan sumber daya alam yang melimpah. Penekanan pada investasi manusia juga diyakini merupakan basis dalam meningkatkan produktivitas faktor produksi secara total (Kuncoro 2004). Sedangkan Todaro (1998) menyatakan bahwa sumber daya manusia dari suatu bangsa merupakan faktor paling menentukan karakter dan kecepatan pembangunan social dan ekonomi dari bangsa yang bersangkutan.

Permasalahan yang dihadapi Provinsi Jawa Timur adalah indeks pendidikan yang rendah. Berdasarkan data BPS, indeks pendidikan Jawa Timur tahun 2014 sebesar 0,581 dan berada pada posisi ke-25 dari 34 provinsi di Indonesia. Indeks pendidikan tersebut berada di bawah rata-rata nasional sebesar 0,602. Nilai indeks pendidikan Jawa Timur berada di bawah nilai dua indeks komponen penyusun Indeks Pembangunan Manusia lainnya. Nilai indeks kesehatan dan indeks pengeluaran Jawa Timur tahun 2014 yaitu 0,776 dan 0,702. Rendahnya

2 nilai indeks pendidikan Jawa Timur turut memberikan kontribusi terhadap rendahnya Indeks Pembangunan Manusia Jawa Timur. Upaya peningkatan indeks pendidikan dinilai dapat meningkatkan Indeks Pembangunan Manusia di Jawa Timur. 
Di era otonomi daerah saat ini, pemerintah daerah mempunyai peran besar dalam mengembangkan pembangunan di daerah. Peranan tersebut dijalankan pemerintah daerah melalui kebijakan-kebijakan pembangunan dan juga melalui kebijakan fiskal berupa pengelolaan keuangan daerah. Salah satu kebijakan pemerintah daerah yang dipandang mampu meningkatkan indeks pendidikan di daerah adalah belanja pemerintah daerah bidang pendidikan. Dengan diserahkannya beberapa kewenangan kepada pemerintah daerah, diharapkan pelayanan masyarakat semakin efisien dan pada gilirannya akan mendorong pertumbuhan ekonomi daerah dan kesejahteraan masyarakat lokal. Para ahli juga berargumen bahwa desentralisasi penerimaan dan pengeluaran merupakan jalan untuk meningkatkan efisiensi di sektor ekonomi (Khusaini, 2006).

Berdasarkan pemaparan di atas, maka kajian ini menganalisis faktor-faktor yang mempengaruhi indeks pendidikan di Jawa Timur serta mencari strategi untuk meningkatkannya. Dengan demikian, permasalahan yang akan dibahas dalam kajian ini adalah sebagai berikut:

a. bagaimana perkembangan kondisi pendidikan di Provinsi Jawa Timur?

b. faktor-faktor apa saja yang mempengaruhi indeks pendidikan di Provinsi Jawa Timur?

c. bagaimana strategi untuk meningkatkan indeks pendidikan di Provinsi Jawa Timur?

Berdasarkan latar belakang dan rumusan masalah yeng telah diuraikan, kajian ini bertujuan untuk:

a. menggambarkan kondisi umum pendidikan di Provinsi Jawa Timur

b. menganalisis faktor-faktor yang berpengaruh terhadap indeks pendidikan di Provinsi Jawa Timur.

c. merumuskan strategi atau program untuk meningkatkan indeks pendidikan di Provinsi Jawa Timur

\section{TINJAUAN PUSTAKA}

\section{Anggaran Pendapatan Dan Belanja Daerah}

Anggaran Pendapatan dan Belanja Daerah (APBD) adalah suatu rencana keuangan tahunan pemerintah daerah yang disetujui oleh Dewan Perwakilan Rakyat Daerah (UU No. 17 Tahun 2003 tentang Keuangan Negara pasal 1 butir 8). Semua penerimaan daerah dan pengeluaran daerah harus dicatat dan dikelola dalam APBD. APBD merupakan dasar pengelolaan keuangan daerah dalam satu tahun anggaran. APBD merupakan rencana pelaksanaan semua pendapatan daerah dan semua belanja daerah dalam rangka pelaksanaan desentralisasi dalam tahun anggaran tertentu. Pemungutan semua penerimaan daerah bertujuan untuk memenuhi target yang ditetapkan dalam APBD. Demikian pula semua 
pengeluaran daerah yang membebani daerah dalam rangka pelaksanaan desentralisasi dilakukan sesuai jumlah dan sasaran yang ditetapkan dalam APBD.

Struktur APBD terdiri atas : (a) pendapatan daerah, (b) belanja daerah, (c) pembiayaan daerah. APBD menjadi dasar pengelolaan keuangan daerah dalam masa satu tahun anggaran. APBD merupakan perwujudan kebijakan fiskal pemerintahan daerah dalam menjalankan program kerja untuk pelayanan umum dan kesejahteraan masyarakat. APBD juga menduduki posisi yang penting dalam pembangunan di daerah. Proses pembangunan di era otonomi daerah memberikan celah dan peluang yang besar bagi pemerintah daerah dalam menentukan kebijakan dan arah pembangunan yang mengutamakan potensi serta keunggulan daerah sesuai dengan karakteristik daerah masing-masing.

\section{Belanja Pemerintah Daerah Bidang Pendidikan}

Menurut Peraturan Menteri Dalam Negeri Nomor 13 Tahun 2006 tentang Pedoman Pengelolaan Keuangan Daerah, belanja daerah adalah kewajiban pemerintah daerah yang diakui sebagai pengurang nilai kekayaan bersih. Belanja daerah dipergunakan dalam rangka pelaksanaan urusan pemerintahan yang menjadi kewenangan provinsi atau kabupaten/kota yang terdiri dari urusan wajib dan urusan pilihan yang ditetapkan dengan ketentuan perundang-undangan.

Urusan wajib adalah urusan yang sangat mendasar yang berkaitan dengan hak dan pelayanan dasar kepada masyarakat yang wajib diselenggarakan oleh pemerintah daerah. Sedangkan urusan pilihan adalah urusan pemerintah yang secara nyata ada dan berpotensi untuk meningkatkan kesejahteraan masyarakat sesuai kondisi, kekhasan, dan potensi keunggulan daerah. Belanja penyelenggaraan urusan wajib tersebut diprioritaskan untuk melindungi dan meningkatkan kualitas kehidupan masyarakat dalam upaya memenuhi kewajiban daerah yang diwujudkan dalam bentuk peningkatan pelayanan dasar, pendidikan, kesehatan, fasilitas sosial dan fasilitas umum yang layak serta mengembangkan sistem jaminan sosial. Peningkatan kualitas kehidupan masyarakat diwujudkan melalui prestasi kerja dalam pencapaian standar pelayanan minimal berdasarkan urusan wajib pemerintahan daerah sesuai dengan peraturan perundang-undangan.

\section{Indeks Pendidikan}

Salah satu komponen pembentuk Indeks Pembangunan Manusia adalah dimensi 4 pengetahuan yang diukur melalui tingkat pendidikan. Indikator yang digunakan untuk mengukur tingkat pendidikan berdasarkan data Indeks Pembangunan Manusia metode terbaru yang dikeluarkan oleh BPS adalah rata-rata lama sekolah (mean years of schooling) dan 
Harapan Lama Sekolah (expected years of schooling). Pada proses pembentukan Indeks Pembangunan Manusia, rata-rata lama sekolah dan harapan lama sekolah diberi bobot yang sama, kemudian penggabungan kedua indikator ini digunakan sebagai indeks pendidikan yang akan menjadi salah satu komponen pembentuk Indeks Pembangunan Manusia.

Rata-rata Lama Sekolah didefinisikan sebagai jumlah tahun yang digunakan oleh penduduk dalam menjalani pendidikan formal (BPS 2015). Diasumsikan bahwa dalam kondisi normal rata-rata lama sekolah suatu wilayah tidak akan turun. Sedangkan cakupan penduduk yang dihitung dalam penghitungan Rata-rata Lama Sekolah adalah penduduk berusia 25 tahun keatas. Usia 25 tahun dipakai batasan berdasarkan rekomendasi UNDP. Selain untuk keterbandingan dengan internasional, alasan penting lain yaitu bahwa pada umumnya penduduk berusia 25 ke atas tidak bersekolah lagi. Walaupun sebagian kecil ada yang masih bersekolah, jumlahnya tidak signifikan. Penduduk usia 25 tahun ke atas merupakan stok pendidikan yang dimiliki oleh suatu wilayah.

Sedangkan Harapan Lama Sekolah (HLS) didefinisikan sebagai lamanya sekolah (dalam tahun) yang diharapkan akan dirasakan oleh anak pada umur tertentu di masa mendatang. Diasumsikan bahwa peluang anak tersebut akan tetap bersekolah pada umur-umur berikutnya sama dengan peluang penduduk yang bersekolah per jumlah penduduk untuk umur yang sama saat ini. Harapan Lama Sekolah dapat digunakan untuk mengetahui kondisi pembangunan sistem pendidikan di berbagai jenjang yang ditunjukkan dalam bentuk lamanya pendidikan (dalam tahun) yang diharapkan dapat dicapai oleh setiap anak. Harapan Lama Sekolah dihitung pada usia 7 tahun ke atas karena mengikuti kebijakan pemerintah yaitu program wajib belajar.

Rumus yang digunakan untuk menghitung indeks pendidikan menurut BPS (2015) adalah:

$$
\begin{aligned}
& \mathbf{I}_{\mathrm{HLS}}=\frac{\mathrm{HLS}-\mathrm{HLS} \min }{\mathrm{HLS} \text { maks }-\mathrm{HLS} \min } \\
& \mathbf{I}_{\mathrm{RLS}}=\frac{\text { RLS }- \text { RLS min }}{\text { RLS maks }- \text { RLS min }} \\
& \mathbf{I}_{\text {pendidikan }}=\frac{\text { I HLS }- \text { I RLS }}{2}
\end{aligned}
$$

Keterangan:

HLS : Harapan Lama Sekolah (tahun)

RLS : Rata-rata Lama Sekolah (tahun)

I $_{\text {pendidikan }}$ : Indeks pendidikan 


\section{METODE PENELITIAN}

Kajian ini menggunakan dua metode analisis yaitu regresi berganda data panel dan Analitycal Hierarchy Process (AHP). Analisis regresi berganda data panel digunakan untuk menganalisis faktor-faktor yang mempengaruhi indeks pendidikan di Jawa Timur. Analisis AHP digunakan untuk merumuskan strategi atau program untuk meningkatkan indeks pendidikan di Jawa Timur. Data yang digunakan dalam penelitian ini ada dua yaitu data sekunder untuk analisis regresi dan data primer untuk analisis AHP.

Data penelitian untuk analisis regresi adalah seluruh kabupaten/kota di Jawa Timur tahun 2010 sampai 2014. Sedangkan untuk analisis AHP, digunakan responden yang dipilih secara sengaja (purposive sampling). Responden yang dipilih yaitu pejabat pada Dinas Pendidikan Provinsi Jawa Timur, pejabat pada Badan Perencanaan Pembangunan Daerah Provinsi Jawa Timur dan anggota DPRD Provinsi Jawa Timur komisi E yang menangani masalah pendidikan.

Variabel-variabel yang digunakan dalam menganalisis faktor-faktor yang mempengaruhi indeks pendidikan di Jawa Timur, yaitu: alokasi belanja pemerintah daerah bidang pendidikan, pendapatan per kapita, Angka Partisipasi Sekolah Dasar, Angka Partisipasi Sekolah Menengah Pertama, Angka Partisipasi Sekolah Menengah Atas, jumlah Sekolah Dasar, jumlah Sekolah Menengah Pertama, jumlah Sekolah Menengah Atas, rasio murid per guru tingkat Sekolah Dasar, rasio murid per guru tingkat Sekolah Menengah Pertama, rasio murid per guru tingkat Sekolah Menengah Atas. Model persamaan regresi yang digunakan adalah sebagai berikut:

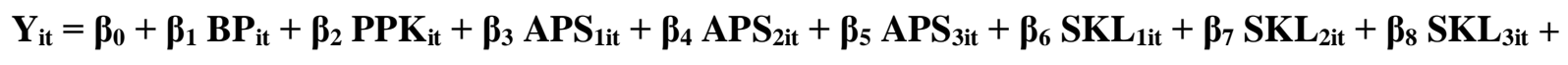

$$
\begin{aligned}
& \beta_{9} R_{M G}+\beta_{10} R_{1 i t} G_{2 i t}+\beta_{11} R_{M G}+e_{i t}
\end{aligned}
$$

Keterangan:

Y : indeks pendidikan

$\beta_{0}-\beta_{11} \quad$ : parameter (koefisien) regresi

BP : Alokasi belanja pemerintah daerah urusan pendidikan (Rp), dengan hipotesis $\beta_{1}>0$

PPK $\quad$ : Pendapatan Per Kapita (Rp), dengan hipotesis $\beta_{2}>0$

APS $_{1} \quad:$ Angka Partisipasi Sekolah Dasar (\%), dengan hipotesis $\beta_{3}>0$

$\mathrm{APS}_{2} \quad$ : Angka Partisipasi Sekolah Menengah Pertama (\%), dengan hipotesis $\beta_{4}>0$

$\mathrm{APS}_{3} \quad:$ Angka Partisipasi Sekolah Menengah Atas (\%), dengan hipotesis $\beta_{5}>0$

$6 \mathrm{SKL}_{1} \quad$ : Jumlah Sekolah Dasar (unit), dengan hipotesis $\beta_{6}>0$

$\mathrm{SKL}_{2} \quad:$ Jumlah Sekolah Menengah Pertama (unit), dengan hipotesis $\beta_{7}>0$

$\mathrm{SKL}_{3} \quad$ : Jumlah Sekolah Menengah Atas (unit), dengan hipotesis $\beta_{8}>0$ 


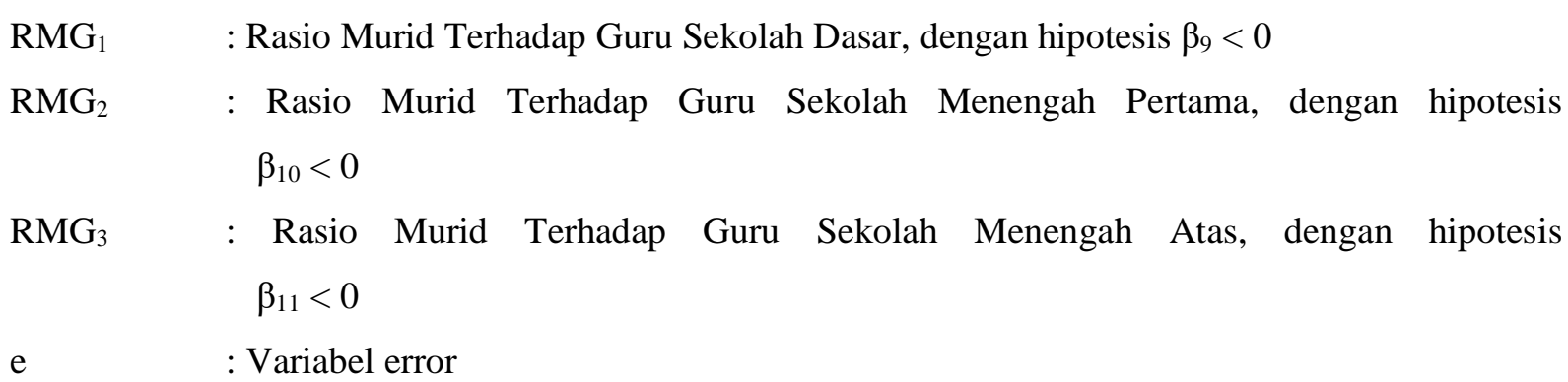

Formulasi strategi atau program dirumuskan melalui analisis AHP berdasarkan pada hirarki strategi. Hirarki prioritas strategi disusun berdasarkan pengamatan, studi literatur dan wawancara dengan pejabat terkait. Struktur hirarki terdiri atas lima level, yaitu level 1 fokus, level 2 aktor, level 3 faktor, level 4 tujuan, dan level 5 strategi.

Tujuan akhir dari perumusan strategi menggunakan analisis AHP adalah pemilihan prioritas strategi yang paling baik untuk strategi peningkatan indeks pendidikan melalui alokasi belanja pemerintah daerah bidang pendidikan. Adapun alternative strategi pada level 5 yaitu: (a) penambahan jumlah sekolah formal dan non formal, (b) rehabilitasi ruang kelas, (c) diklat/workshop untuk tenaga pendidik, (d) bantuan biaya operasional pada sekolah non formal, (e) pemerataan kuantitas tenaga pendidik, (f) beasiswa siswa kurang mampu. Hirarki Analytical Hierarcy Process strategi peningkatan indeks pendidikan melalui alokasi belanja pemerintah daerah bidang pendidikan disajikan pada Gambar 1.

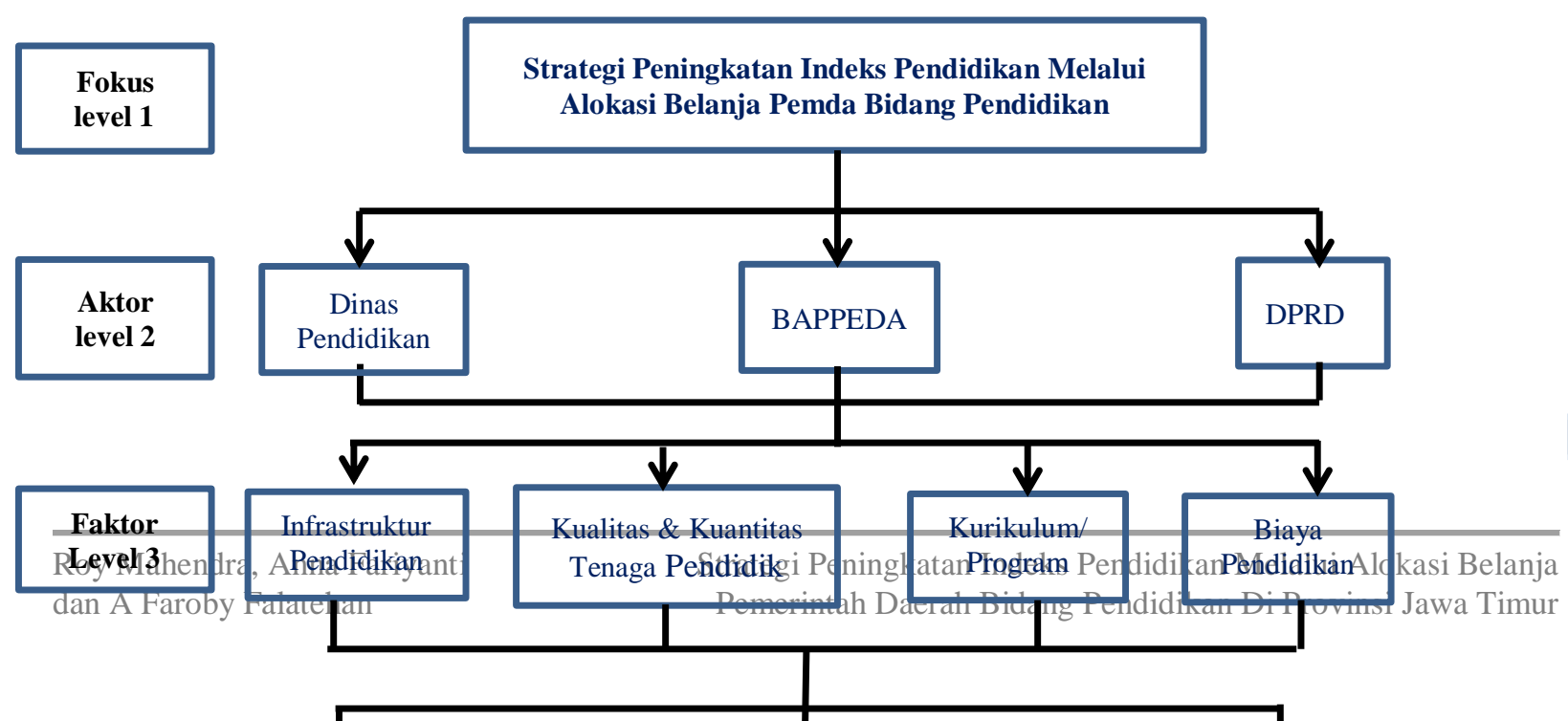


Gambar 1 Hirarki Analytical Hierarcy Process (AHP)

\section{HASIL DAN PEMBAHASAN}

\section{Indeks Pendidikan di Jawa Timur}

Posisi IPM Jawa Timur tahun 2014 menempati urutan ke-18 dari 34 provinsi di Indonesia. Rendahnya IPM di Jawa Timur salah satunya dipengaruhi oleh nilai indeks pendidikan di Jawa Timur. Data masing-masing komponen IPM untuk kota/kabupaten di Provinsi Jawa Timur tahun 2014 disajikan pada Tabel 1.

Dari data komponen penyusun IPM pada Tabel 1, dapat dilihat perbandingan masingmasing komponen dari IPM yaitu indeks kesehatan, indeks pendidikan, dan indeks pengeluaran antar kabupaten/kota di Provinsi Jawa Timur tahun 2014. Dari ketiga komponen penyusunnya, komponen indeks pendidikan adalah komponen yang memiliki nilai terendah dibanding dengan komponen yang lainnya.

Tabel 1 Daftar komponen IPM kota/kabupaten di Jawa Timur tahun 2014

\begin{tabular}{llllll}
\hline No. & Kabupaten & $\begin{array}{l}\text { Indeks } \\
\text { Kesehatan }\end{array}$ & $\begin{array}{l}\text { Indeks } \\
\text { Pendidikan }\end{array}$ & Indeks Pengeluaran & IPM \\
\hline $\mathbf{1}$ & Jawa Timur & $\mathbf{0 . 7 7 6}$ & $\mathbf{0 . 5 8 1}$ & $\mathbf{0 . 7 0 2}$ & $\mathbf{6 8 . 1 4}$ \\
2 & Pacitan & 0.781 & 0.537 & 0.620 & 63.81 \\
3 & Ponorogo & 0.798 & 0.593 & 0.647 & 67.40 \\
4 & Trenggalek & 0.808 & 0.552 & 0.649 & 66.16 \\
5 & Tulung Agung & 0.814 & 0.602 & 0.686 & 69.49 \\
6 & Blitar & 0.808 & 0.547 & 0.678 & 66.88 \\
7 & KedirI & 0.801 & 0.581 & 0.690 & 68.44 \\
8 & Malang & 0.797 & 0.535 & 0.663 & 65.59 \\
9 & Lumajang & 0.755 & 0.510 & 0.629 & 62.33 \\
10 & Jember & 0.735 & 0.521 & 0.642 & 62.64 \\
11 & Banyuwangi & 0.768 & 0.557 & 0.713 & 67.31 \\
12 & Bondowoso & 0.699 & 0.541 & 0.675 & 63.43 \\
8 & Situbondo & 0.740 & 0.545 & 0.648 & 63.91 \\
13 & Probolinggo & 0.704 & 0.510 & 0.698 & 63.04 \\
15 & Pasuruan & 0.767 & 0.539 & 0.645 & 64.35 \\
16 & Sidoarjo & 0.822 & 0.713 & 0.773 & 76.78 \\
17 & Mojokerto & 0.796 & 0.591 & 0.736 & 6.22 \\
18 & Jombang & 0.790 & 0.602 & 0.693 & 69.07
\end{tabular}




\begin{tabular}{|c|c|c|c|c|}
\hline Nganjuk & 0.783 & 0.595 & 0.724 & 69.59 \\
\hline Madiun & 0.766 & 0.585 & 0.721 & 68.60 \\
\hline Magetan & 0.799 & 0.606 & 0.717 & 70.29 \\
\hline Ngawi & 0.790 & 0.559 & 0.706 & 67.78 \\
\hline Bojonegoro & 0.771 & 0.540 & 0.668 & 65.27 \\
\hline Tuban & 0.773 & 0.523 & 0.666 & 64.58 \\
\hline Lamongan & 0.792 & 0.615 & 0.687 & 69.42 \\
\hline Gresik & 0.803 & 0.647 & 0.744 & 72.84 \\
\hline Bangkalan & 0.763 & 0.479 & 0.612 & 60.71 \\
\hline Sampang & 0.731 & 0.405 & 0.626 & 56.98 \\
\hline Pamekasan & 0.716 & 0.561 & 0.613 & 62.66 \\
\hline Sumenep & 0.770 & 0.503 & 0.599 & 61.43 \\
\hline Kota Kediri & 0.823 & 0.699 & 0.722 & 74.62 \\
\hline Kota Blitar & 0.811 & 0.702 & 0.749 & 75.26 \\
\hline Kota Malang & 0.805 & 0.734 & 0.833 & 78.96 \\
\hline Kota Probolinggo & 0.762 & 0.651 & 0.707 & 70.49 \\
\hline Kota Pasuruan & 0.778 & 0.678 & 0.745 & 73.23 \\
\hline Kota Mojokerto & 0.806 & 0.700 & 0.749 & 75.04 \\
\hline Kota Madiun & 0.806 & 0.742 & 0.818 & 78.81 \\
\hline Kota Surabaya & 0.829 & 0.709 & 0.835 & 78.87 \\
\hline Kota Batu & 0.801 & 0.639 & 0.726 & 71.89 \\
\hline
\end{tabular}

Sumber: BPS 2015, diolah.

Nilai indeks pendidikan rata-rata Jawa Timur adalah 0,581. Jika indeks pendidikan kota/kabupaten dibagi dua dengan batasan rata-rata Jawa Timur, terdapat 19 kota/kabupaten di atas rata-rata Jawa Timur dan 19 kota/kabupaten di bawah rata-rata Jawa Timur. Indeks pendidikan tertinggi hampir semuanya ditempati oleh daerah kota. Sedangkan daerah-daerah dengan indeks pendidikan di bawah rata-rata Jawa Timur semuanya adalah daerah kabupaten. Hal ini membuktikan bahwa terdapat kesenjangan indeks pendidikan antara daerah kota dengan kabupaten. Daerah kota yang lebih unggul dari sisi infrastruktur dan dari sisi ekonomi cenderung memiliki indeks pendidikan yang tinggi.

Indeks pendidikan di bawah rata-rata di Jawa Timur sebagian besar ditempati kabupaten-kabupaten di Pulau Madura dan juga daerah tapal kuda (Kab. Jember, Lumajang, Bondowoso, Probolinggo, Pasuruan). Hal ini salah satunya dipengaruhi oleh budaya masyarakat yang menganggap tidak penting untuk mencapai sekolah sampai tinggi. Bahkan daerah dengan indeks pendidikan tiga terendah ditempati oleh kabupaten di Madura yaitu Kabupaten Sampang (urutan 39), Kabupaten Bangkalan (urutan 38), dan Kabupaten Sumenep (urutan 37). Secara umum, hal ini menunjukkan bahwa sektor pendidikan di kabupaten di Pulau Madura relatif tertinggal dibandingkan daerah lainnya di Pulau Jawa (Jawa Timur). Indikasi ini menunjukkan kesenjangan kualitas pendidikan di Jawa Timur antara daerahdaerah di Pulau Madura dan daerah tapal kuda jika dibandingkan dengan daerah lainnya lebih-lebih daerah kota.

\section{Perkembangan Alokasi Belanja Bidang Pendidikan}

Secara umum, alokasi belanja pemerintah daerah bidang pendidikan di kabupaten/kota di Jawa Timur semakin meningkat dari tahun ke tahun. Alokasi dana pendidikan bertujuan untuk membiayai segala aktivitas dan pembangunan di bidang pendidikan. Dengan meningkatnya anggaran bidang pendidikan diharapkan terjadi peningkatan kualitas sumber 
daya manusia di Jawa Timur yang indikatornya salah satunya peningkatan nilai indeks pendidikan. Data alokasi belanja pemerintah daerah kabupaten dan kota se-provinsi Jawa Timur dapat dilihat pada Gambar 2.

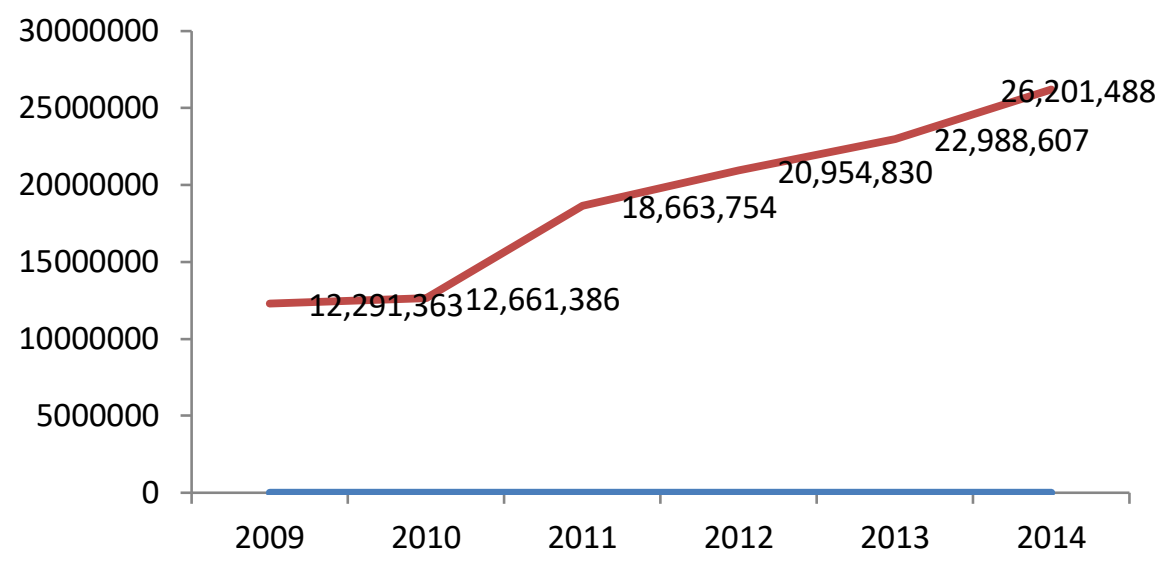

Sumber: DJPK 2015, diolah.

Gambar 2 Total alokasi belanja bidang pendidikan kabupaten/kota se-Jawa Timur (dalam jutaan Rupiah) tahun 2009 - 2014

Kenaikan alokasi belanja pemerintah bidang pendidikan dari tahun 2009 sampai 2014 juga diikuti dengan trend kenaikan indeks pendidikan. Berdasarkan data dari BPS, kenaikan indeks pendidikan dari tahun 2010 sampai dengan 2014 secara berturut-turut adalah 0,544, 0,549, 0,554, 0,568, 0,581. Namun demikian, indeks pendidikan di Provinsi Jawa Timur tahun 2014 masih berada di bawah rata-rata indeks pendidikan secara nasional yaitu 0,602. Perlu adanya program atau strategi yang dijalankan oleh pemerintah daerah untuk meningkatkan indeks pendidikan di Jawa Timur.

\section{Faktor-Faktor yang Mempengaruhi Indeks Pendidikan di Jawa Timur}

Sebelum dilakukan analisis faktor-faktor yang mempengaruhi indeks pendidikan di Jawa Timur, diperlukan pemilihan model regresi berganda data panel. Hasil pengujian yang dilakukan untuk pemilihan model melalui uji Chow dan uji Hausman, didapatkan bahwa model yang lebih baik digunakan pada model adalah FEM. Setelah dipilih model yang paling sesuai, maka dilakukan estimasi dari persamaan yang telah ditentukan. Hasil estimasi yang dilakukan dengan menggunakan aplikasi eViews 7 didapatkan hasil seperti pada Tabel 2.

Tabel 2 Hasil estimasi faktor-faktor yang mempengaruhi indeks pendidikan di Jawa Timur

\begin{tabular}{lrrrr}
\hline Variable & Coefficient & Std. Error & Prob. & Elastisitas \\
\hline BP & $4.42 \mathrm{E}-08$ & $9.07 \mathrm{E}-09$ & $0.0000^{*}$ & 0,041 \\
PPK & $5.05 \mathrm{E}-07$ & $1.37 \mathrm{E}-07$ & $0.0003^{*}$ & 0,030 \\
APS1 & $-8.42 \mathrm{E}-05$ & 0.000138 & 0.5422 & $-0,015$ \\
APS2 & 0.001134 & 0.000309 & $0.0003^{*}$ & 0,185 \\
APS3 & 0.000551 & 0.000150 & $0.0003^{*}$ & 0,063 \\
SKL1 & $3.63 \mathrm{E}-05$ & $4.71 \mathrm{E}-05$ & 0.4425 & 0,033
\end{tabular}




\begin{tabular}{|c|c|c|c|c|}
\hline SKL2 & $-2.86 \mathrm{E}-05$ & 0.000138 & 0.8365 & -0.005 \\
\hline SKL3 & $-1.99 \mathrm{E}-05$ & 0.000158 & 0.9001 & -0.002 \\
\hline RMG1 & 0.001183 & 0.000310 & $0.0002 *$ & \\
\hline RMG2 & 0.000288 & 0.000190 & 0.1315 & \\
\hline RMG3 & -0.001014 & 0.000643 & 0.1171 & \\
\hline $\mathrm{C}$ & 0.370594 & 0.037964 & 0.0000 & \\
\hline R-squared & 0.986579 & & & \\
\hline Adjusted R-squared & 0.982010 & & & \\
\hline S.E. of regression & 0.010518 & & & \\
\hline F-statistic & $215.94 *$ & & & \\
\hline Durbin-Watson stat & 1.472197 & & & \\
\hline
\end{tabular}

*signifikan pada $\alpha=1 \%$

Analisis regresi data panel faktor-faktor yang mempengaruhi indeks pendidikan di Jawa Timur menghasilkan nilai koefisien determinasi atau R-square sebesar 98,66\% berarti keragaman variabel dependen dapat dijelaskan oleh variabel-variabel independen dalam model sebesar 98,66\%, sedangkan sisanya sebesar $1,34 \%$ dijelaskan oleh variabel lain diluar model. Nilai $\mathrm{F}$ hitung sebesar 215,94 signifikan pada taraf $1 \%$ menunjukkan bahwa variabelvariabel independen secara bersama-sama berpengaruh secara signifikan terhadap variable IP (Indeks Pendidikan). Indikator nilai $\mathrm{F}$ hitung tersebut menunjukkan bahwa model yang digunakan cukup baik dan layak digunakan. Konstanta sebesar 0,3706 menunjukkan bahwa jika tidak terdapat kenaikan atau penurunan dari nilai variabel-variabel independen maka nilai indeks pendidikan berada pada angka 0,3706.

Hasil estimasi faktor-faktor yang mempengaruhi indeks pendidikan menunjukkan bahwa variabel-variabel independen yang berpengaruh secara signifikan dan positif adalah variabel alokasi belanja pemerintah daerah bidang pendidikan, pendapatan per kapita, Angka Partisipasi Sekolah SMP, Angka Partisipasi Sekolah SMA, dan rasio murid per guru tingkat SD.

Variabel alokasi belanja pemerintah daerah bidang pendidikan memiliki pengaruh positif dan signifikan terhadap indeks pendidikan. Variabel belanja pemerintah daerah bidang pendidikan mempunyai tingkat elastisitas sebesar 0,041 yang artinya setiap kenaikan $1 \%$ alokasi belanja pemerintah daerah bidang pendidikan akan menaikkan indeks pendidikan sebesar $0,041 \%$, dengan asumsi variabel-variabel lainnya tetap. Hasil analisis pengaruh alokasi belanja pemerintah daerah bidang pendidikan terhadap indeks pendidikan ini sejalan dengan hasil penelitian Yanuarta (2009), Sumas (2012), Mauriza et al (2013), Ilhami (2014), Sanggelorang et al (2015), Widodo et al (2011), Astri (2013), Oriakhi dan Ameh (2014), Fattah dan Muji (2012).

Dari hasil analisis regresi berganda data panel, dapat dilihat bahwa alokasi belanja pemerintah daerah bidang pendidikan berpengaruh positif terhadap indeks pendidikan (IPM bidang pendidikan). Kenaikan alokasi belanja pemerintah bidang pendidikan dari tahun 2010 
sampai 2014 (Gambar 2) bisa berpengaruh terhadap kenaikan indeks pendidikan Provinsi Jawa Timur. Namun demikian, indeks pendidikan Provinsi Jawa Timur masih tergolong rendah karena berada di bawah rata-rata nasional. Menurut penelitian Ilhami (2014), provinsi yang memiliki anggaran pendidikan per kapita usia sekolah terbesar adalah Kalimantan Timur dan Papua Barat. Sedangkan provinsi yang memiliki anggaran pendidikan per kapita penduduk usia sekolah yang relatif kecil adalah Provinsi Jawa Barat, Banten dan Jawa Timur. Hal ini menandakan bahwa penduduk usia sekolah di tiga provinsi ini menikmati anggaran pendidikan yang lebih sedikit daripada penduduk usia sekolah di provinsi lainnya. Penelitian Ilhami (2014) juga menghasilkan kesimpulan adanya peningkatan anggaran pendidikan per kapita penduduk usia sekolah dari tahun ke tahun pada pemerintah daerah Provinsi Jawa Timur. Penelitian dilakukan dengan mengambil sampel provinsi-provinsi di Indonesia dari tahun 2004 sampai 2012.

Variabel pendapatan per kapita memiliki pengaruh positif dan signifikan terhadap indeks pendidikan. Variabel pendapatan per kapita mempunyai tingkat elastisitas sebesar 0,030 yang artinya setiap kenaikan $1 \%$ pendapatan per kapita akan menaikkan indeks pendidikan sebesar 0,030\%, dengan asumsi variabel-variabel lainnya tetap. Hasil analisis pengaruh pendapatan per kapita terhadap indeks pendidikan ini sejalan dengan hasil kajian Sofilda (2015), Melliana dan Zain (2013). Sofilda (2015) menghasilkan kesimpulan dalam penelitiannya bahwa pengeluaran pemerintah berpengeruh terhadap pertumbuhan pendapatan per kapita, sedangkan pertumbuhan pendapatan per kapita berpengaruh positif terhadap IPM.

Variabel Angka Partisipasi Sekolah tingkat SMP memiliki pengaruh positif dan signifikan terhadap indeks pendidikan. Variable Angka Partisipasi Sekolah tingkat SMP mempunyai tingkat elastisitas sebesar 0,185 yang artinya setiap kenaikan $1 \%$ Angka Partisipasi Sekolah tingkat SMP akan menaikkan indeks pendidikan sebesar 0,185\%, dengan asumsi variabel-variabel lainnya tetap.

Variabel Angka Partisipasi Sekolah tingkat SMA memiliki pengaruh positif dan signifikan terhadap indeks pendidikan. Variabel Angka Partisipasi Sekolah tingkat SMA mempunyai tingkat elastisitas sebesar 0,063 yang artinya setiap kenaikan $1 \%$ Angka Partisipasi Sekolah tingkat SMA akan menaikkan indeks pendidikan sebesar 0,063\%, dengan asumsi variabel-variabel lainnya tetap. Penelitian Hasbullah et al (2012) serta Melliana dan Zain (2013) juga menghasilkan kesimpulan bahwa untuk meningkatkan Indeks Pembangunan Manusia dapat dilakukan dengan menaikkan Angka Partisipasi Sekolah (APS).

1 Variabel rasio murid per guru tingkat SD memiliki pengaruh signifikan dan positif terhadap indeks pendidikan. Variabel rasio murid per guru tingkat SD mempunyai koefisien regresi sebesar 0,001183 yang artinya setiap kenaikan rasio murid per guru tingkat SD sebesar 
satu satuan maka akan menaikkan indeks pendidikan sebesar 0,001183, dengan asumsi variabel-variabel lainnya tetap. Pengaruh rasio murid per guru tingkat SD terhadap indeks pendidikan bersifat positif diduga terjadi karena rasio jumlah siswa dibandingkan dengan jumlah guru mengalami fluktuatif dari tahun 2010 sampai 2014. Rasio jumlah siswa dibandingkan dengan jumlah guru menunjukkan tren yang meningkat pada tahun penelitian. Hal ini menunjukkan terjadi peningkatan jumlah siswa antara tahun 2010 sampai 2014 atau penurunan jumlah guru pada tahun 2010 sampai 2014. Penurunan jumlah guru bisa disebabkan lebih banyak guru yang keluar (pensiun atau berhenti) daripada jumlah yang diterima menjadi guru.

Hasil kajian pengaruh rasio murid per guru terhadap indeks pendidikan berbeda dengan hasil kajian Evianto (2010). Evianto (2010) menggunakan variabel rasio guru terhadap murid pada tingkat SMP pada analisis faktor-faktor yang mempengaruhi Indeks Pembangunan Manusia di Provinsi Jawa Barat tahun 2001-2007. Hasil kajian Evianto (2010) menunjukkan bahwa variabel rasio guru terhadap murid tingkat SMP berpengaruh secara signifikan dan positif terhadap nilai IPM.

\section{Strategi Untuk Meningkatkan Indeks Pendidikan di Jawa Timur}

Hasil analisis untuk menentukan strategi peningkatan indeks pendidikan melalui alokasi belanja pemerintah daerah bidang pendidikan dengan metode AHP menghasilkan prioritas strategi. Hirarki dan nilai yang dihasilkan oleh analisis AHP disajikan pada Gambar 3.

Berdasarkan perbandingan antar unsur "Aktor" berdasarkan "Fokus", prioritas pertama adalah Dinas Pendidikan Provinsi Jawa Timur dan BAPPEDA Provinsi Jawa Timur dengan nilai 0,375. Prioritas selanjutnya adalah DPRD dengan nilai 0,250. Dinas Pendidikan Provinsi Jawa Timur dipilih untuk lebih diprioritaskan oleh ahli karena merupakan instansi yang secara secara teknis langsung mengurusi masalah pendidikan di daerah. BAPPEDA Provinsi Jawa Timur dipilih karena merupakan instansi yang melakukan analisis dan pengkajian terhadap pembangunan termasuk masalah pendidikan. DPRD Provinsi Jawa Timur berada di prioritas urutan kedua DPRD merupakan faktor pendukung untuk mensukseskan pembangunan bidang pendidikan di Jawa Timur. Peran DPRD untuk bidang pendidikan sesuai dengan tugas dan fungsinya yaitu bidang legeslasi, anggaran, dan pengawasan.

Perbandingan antar elemen "Faktor" berdasarkan "Aktor" yang menempati urutan pertama yaitu kualitas \& kuantitas tenaga pendidik dengan nilai 0,363, urutan selanjutnya adalah biaya pendidikan dengan nilai 0,278 , infrastruktur pendidikan dengan nilai 0,231 , serta kurikulum/program dengan nilai 0,128 . Responden yang dianggap ahli berpendapat bahwa kualitas dan kuantitas tenaga pendidik menjadi faktor yang paling diprioritaskan karena 
dengan kualitas dan kuantitas tenaga pendidik yang baik proses belajar mengajar dapat dijalankan secara baik walaupun dengan fasilitas yang minim. Faktor tenaga pendidik yang berkualitas mampu menciptakan cara belajar yang efektif dan kreatif sehingga proses transfer ilmu dapat berjalan dengan baik. Pendidik (guru) yang kompeten mampu menyiasati fasilitas yang minim sehingga murid-murid dapat memahami pelajaran dengan baik.

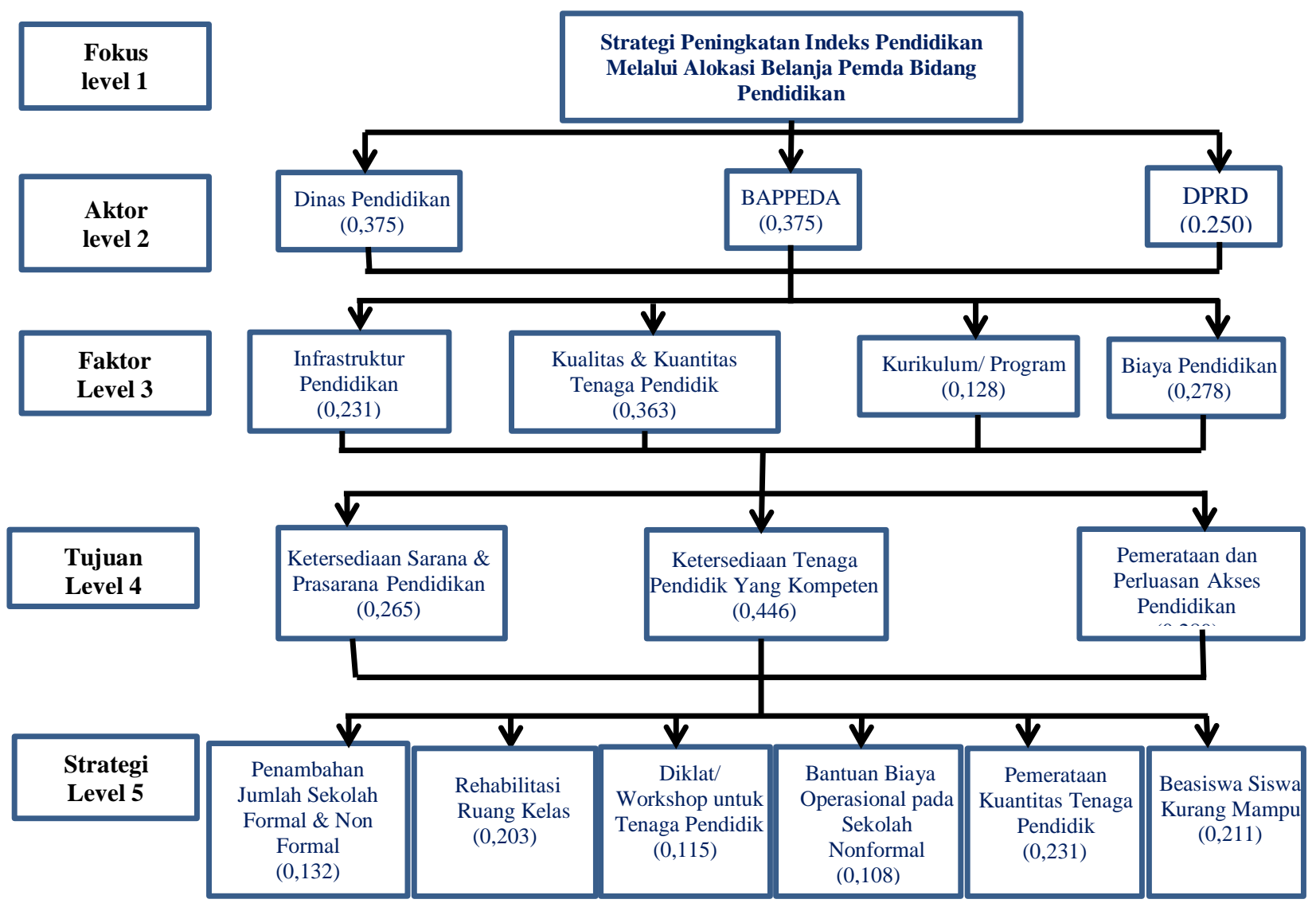

Gambar 3 Hirarki dan skor hasil analisis AHP

Perbandingan antar elemen "Tujuan" berdasarkan "Faktor" yang menempati prioritas pertama untuk meningkatkan indeks pendidikan yaitu ketersediaan tenaga pendidik yang kompeten dengan nilai 0,446 , prioritas selanjutnya yaitu pemerataan dan perluasan akses pendidikan dengan nilai 0,289, serta prioritas ketiga yaitu ketersediaan sarana \& prasarana pendidikan dengan nilai 0,265 . Menurut ahli yang menjadi responden, ketersediaan tenaga pendidik yang kompeten merupakan prioritas pertama untuk elemen tujuan. Ketersediaan tenaga pendidik mutlak diperlukan agar proses belajar mengajar dapat dilaksanakan dengan baik dan tujuan pembelajaran dapat tercapai. Tenaga pendidik dan murid adalah unsur utama dalam proses pendidikan. Sukses tidaknya transfer ilmu dalam proses belajar mengajar sangat ditentukan oleh ketersediaan tenaga pendidik yang kompeten. Oleh karena itu, ketersediaan tenaga pendidik yang kompeten menjadi prioritas pertama. 
Perbandingan antar elemen "Strategi" berdasarkan "Tujuan" yang menempati prioritas pertama untuk meningkatkan indeks pendidikan yaitu melakukan pemerataan kuantitas tenaga pendidik dengan nilai sebesar 0,231. Prioritas strategi berikutnya adalah memberikan beasiswa kurang mampu dengan nilai sebesar 0,211. Prioritas ketiga dan seterusnya adalah melakukan rehabilitasi ruang kelas $(0,203)$, menambah jumlah sekolah formal \& nonformal $(0,132)$, mengadakan diklat/workshop untuk tenaga pendidik $(0,115)$, serta memberikan bantuan biaya operasional pada sekolah nonformal $(0,108)$. Responden menilai bahwa strategi yang perlu dijadikan prioritas pertama adalah pemerataan kuantitas tenaga pendidik. Saat ini terjadi kesenjangan jumlah guru di sekolah-sekolah di kota dibandingkan dengan jumlah guru di sekolah-sekolah di desa atau pelosok. Hal ini menyebabkan kesenjangan kualitas pendidikan di kota dan di desa begitu mencolok. Tenaga pendidik masih dianggap sebagai faktor dominan dalam proses pendidikan. Persebaran jumlah tenaga pendidik secara merata di berbagai pelosok akan mengurangi kesenjangan kualitas pendidikan antara kota dan daerah desa/pelosok. Pemerataan jumlah guru ke daerah-daerah pelosok seharusnya dilakukan oleh instansi berwenang agar kualitas pendidikan terutama indeks pendidikan dapat ditingkatkan di daerah.

\section{Implikasi Kebijakan}

Implementasi kebijakan berdasarkan tiga prioritas pertama hasil analisis AHP strategi peningkatan indeks pendidikan melalui alokasi belanja pemerintah daerah bidang pendidikan di Jawa Timur yaitu: (a) pemerataan kuantitas tenaga pendidik, (b) beasiswa kurang mampu, (c) rehabilitasi ruang kelas. Prioritas strategi-strategi tersebut dapat dijabarkan ke dalam program atau kegiatan sebagai berikut:

\section{Pemerataan Kuantitas Tenaga Pendidik}

Peran tenaga pendidik dalam proses pendidikan sangat besar. Setiap upaya meningkatkan kualitas pendidikan seharusnya dimulai dari tenaga pendidik. Permasalahan yang dihadapi banyak daerah termasuk di provinsi Jawa Timur adalah kesenjangan kualitas pendidikan antara di kota dan di desa, antara daerah yang kaya dengan daerah yang miskin. Tenaga pendidik lebih banyak yang memilih untuk bertugas di daerah kota dibandingkan di daerah. Salah satu faktor yang mempengaruhinya adalah faktor ketersediaan infrastruktur yang lebih memadai di kota dibandingkan di daerah. Ketidakmerataan tenaga pendidik antara kota dan daerah menyebabkan terjadi kesenjangan mutu pendidikan.

Kesenjangan jumlah tenaga pendidik antara kota dan daerah dapat diatasi dengan pola mutasi ataupun rotasi. Pemerataan kuantitas tenaga pendidik melalui mutasi dan rotasi 
dilakukan sebagai upaya untuk meratakan kualitas/mutu pendidikan. Idealnya mutasi maupun rotasi tenaga pendidik dilakukan berdasarkan kebutuhan dan pemerataan tenaga pendidik di suatu daerah. Pola mutasi dan rotasi tenaga pendidik seharusnya dijalankan berdasarkan pemetaan kebutuhan dan system yang adil dan terbuka. Hal ini disebabkan mekanisme mutasi dan rotasi tenaga pendidik/ PNS rawan disalahgunakan oleh pejabat tertentu dengan tujuan tertentu. Jika pola mutasi dan rotasi dilakukan secara tidak adil dan transparan, maka akan menimbulkan masalah baru sedangkan masalah pemerataan tenaga pendidik tidak terselesaikan.

Proses pemerataan kuantitas tenaga pendidik sebagai upaya pemerataan mutu pendidikan harus didukung dengan peraturan yang jelas dan pelaksanaan yang adil. Dengan pola pelaksanaan mutasi dan rotasi yang transparan dan adil menjadikan tenaga pendidik lebih tenang dalam menjalankan tugas. Walaupun dalam pelaksanaannya selalu saja ada yang merasa dirugikan dalam setiap kebijakan pemerataan kuantitas tenaga pendidik. Namun, urgensi pemerataan tenaga pendidik antar daerah yang padat ke daerah yang kurang tenaga pendidiknya sangat diperlukan untuk pemerataan kualitas pendidikan.

Strategi pemerataan kuantitas tenaga pendidik bisa dilakukan melalui kegiatan: (a) pemetaan kuantitas tenaga pendidik seluruh kabupaten dan kota, (b) evaluasi pola mutasi dan rotasi tenaga pendidik yang sudah dilakukan, (c) pembuatan peraturan tentang ketentuan mutasi dan rotasi di kabupaten/kota maupun antar kabupaten/kota, (d) mutasi dan rotasi tenaga pendidik di kota/kabupaten ataupun antar kabupaten/kota.

\section{Beasiswa Siswa Kurang Mampu}

Salah satu faktor yang membatasi masyarakat untuk dapat mengakses pendidikan adalah faktor biaya. Salah satu upaya pemerintah agar pendidikan dapat diakses oleh sebanyakbanyaknya masyarakat adalah dengan membuat pendidikan gratis. Namun, karena keterbatasan sumber daya, tidak semua pemerintah daerah melakukan kebijakan pendidikan gratis. Salah satu upaya membantu masyarakat agar tetap dapat mengakses pendidikan selain pendidikan gratis adalah dengan memberikan beasiswa pada siswa kurang mampu.

Beasiswa siswa kurang mampu merupakan upaya ditujukan untuk golongan masyarakat yang kesulitan mengakses pendidikan karena faktor biaya. Bagi sebagian masyarakat, terutama dari golongan masyarakat kurang mampu, biaya pendidikan yang tinggi membuat mereka tidak mampu mengakses pendidikan. Golongan masyarakat kurang mampu juga rawan untuk putus sekolah. Pemberian beasiswa khususnya bagi kalangan tertentu diharapkan

1 dapat memenuhi segala kebutuhan dalam proses belajar agar pendidikan dapat dilaksanakan dengan baik. 
Pemberian beasiswa siswa kurang mampu diharapkan dapat menekan angka siswa putus sekolah serta menaikkan angka partisipasi sekolah. Walaupun selama ini sudah berlangsung program Bantuan Operasional Sekolah (BOS) yang menggratiskan biaya sekolah, namun biaya sekolah seperti biaya seragam, biaya buku serta biaya transportasi masih dirasa memberatkan bagi golongan kurang mampu. Pemberian bantuan beasiswa siswa kurang mampu dapat meringankan mereka untuk tetap melanjutkan sekolah

Pelaksanaan strategi pemberian beasiswa siswa kurang mampu dapat dijalankan dengan kegiatan : (a) pemberiaan beasiswa siswa kurang mampu, (b) evaluasi ketepatan sasaran penerima beasiswa, (c) perluasan cakupan sasaran penerima beasiswa siswa miskin.

\section{Rehabilitasi Ruang Kelas}

Perluasan akses dan peningkatan mutu pendidikan harus diimbangi dengan penguatan regulasi, penataan lembaga, penganggaran pendidikan, tata kelola sekolah serta pemenuhan sarana dan prasarana pendidikan. Proses pendidikan yang baik didukung oleh fasilitas sarana prasarana pendidikan yang memadai. Salah satu sarana utama agar proses belajar mengajar dapat berjalan lancar adalah ruang kelas. Ruang kelas menjadi sarana prasarana penunjang pendidikan yang harus ada sebelum sarana pendidikan yang lainnya.

Strategi rehabilitasi ruang kelas dapat dilaksanakan dengan beberapa kegiatan: (a) pemetaan dan penilaian sekolah-sekolah yang memiliki gedung/ruang kelas rusak, (b) rehabilitasi sekolah/ ruang kelas sekolah dasar, (c) rehabilitasi sekolah/ ruang kelas sekolah menengah

\section{SIMPULAN DAN SARAN}

\section{Simpulan}

Berdasarkan hasil analisis dan pembahasan yang disajikan sebelumnya, dapat disimpulkan beberapa hal sebagai berikut:

1. Indeks pendidikan di Jawa Timur tahun 2010-2014 relatif rendah bila dibandingkan dengan indeks pendidikan provinsi lain. Rendahnya kualitas pendidikan di Jawa Timur yang ditunjukkan dengan indikator indeks pendidikan disebabkan rendahnya indeks pendidikan di kabupaten-kabupaten di Pulau Madura dan daerah tapal kuda seperti Kabupaten Probolinggo, Situbondo, Bondowoso, Jember, Lumajang. Hal ini disebabkan kurangnya kesadaran tentang pentingnya pendidikan di daerah-daerah tersebut.

2. Faktor alokasi belanja pemerintah daerah bidang pendidikan berpengaruh secara positif terhadap indeks pendidikan di Jawa Timur. Faktor-faktor lain yang secara signifikan mempengaruhi indeks pendidikan di Jawa Timur secara positif yaitu variabel pendapatan per kapita, Angka Partisipasi Sekolah tingkat SMP. 
3. Strategi untuk meningkatkan indeks pendidikan di Jawa Timur melalui alokasi belanja pemerintah daerah bidang pendidikan berdasarkan metode AHP, prioritas pertama yaitu pemerataan kuantitas tenaga pendidi. Prioritas strategi berikutnya adalah beasiswa kurang mampu. Prioritas ketiga dan seterusnya adalah rehabilitasi ruang kelas, penambahan jumlah sekolah formal \& nonformal, diklat/workshop untuk tenaga pendidik, serta bantuan biaya operasional pada sekolah nonformal.

\section{Saran}

Berdasarkan hasil kajian, beberapa hal yang perlu dipertimbangkan sebagai saran adalah sebagai berikut:

1. Pemerintah daerah Provinsi Jawa Timur khususnya Dinas Pendidikan perlu lebih memperhatikan daerah-daerah di Pulau Madura dan daerah tapal kuda untuk memberikan pemahaman tentang pentingnya arti pendidikan. Dengan kesadaran masyarakat tentang arti pentingnya pendidikan, diharapkan dapat meningkatkan indeks pendidikan di daerah tersebut dan akhirnya akan meningkatkan indeks pendidikan Jawa Timur secara keseluruhan.

2. Perlu adanya alokasi belanja bidang pendidikan yang cukup untuk meningkatkan kualitas sumber daya manusia di daerah. Belanja pendidikan yang dikeluarkan oleh pemerintah daerah akan menjadi investasi pada kualitas sumber daya manusia yang pada masa yang akan datang dapat berpengaruh terhadap daya saing daerah yang lebih bagus. Faktor lainnya yang perlu diperhatikan untuk peningkatan indeks pendidikan di Jawa Timur adalah Angka Partisipasi Sekolah tingkat SMP, Angka Partisipasi Sekolah tingkat SMA.

3. Pada kajian yang akan datang dengan tema yang sama, disarankan agar memilih responden AHP pada pejabat tingkat kabupaten/kota. Hal ini disarankan dengan alasan agar didapatkan perspektif yang berbeda dari pejabat di daerah serta pejabat di tingkat kabupaten/kota memiliki pengetahuan yang lebih spesifik.

\section{DAFTAR PUSTAKA}

[BPS] Badan Pusat Statistik. 2015. Indeks Pembangunan Manusia 2014 Metode Baru. Jakarta (ID): Badan Pusat Statistik.

[BPS] Badan Pusat Statistik. 2015. Laporan Ekskutif: Statistik Pendidikan Provinsi Jawa Timur 2014. Surabaya (ID): Badan Pusat Statistik.

Evianto E. 2010. Analisis Disparitas Indeks Pembangunan Manusia Kabupaten/Kota di Provinsi Jawa Barat dan Faktor-Faktor Yang Mempengaruhi Capaiannya [tesis]. Jakarta (ID): Universitas Indonesia.

Fattah S, Muji A. 2012. Local Government Expenditure Allocation toward Human Development Index at Janeponto Regency, South Sulawesi, Indonesia. Journal Of 
Humanities And Social Science (JHSS). Issued 6, Nov. 2012 [Internet]. Diunduh 2015

Desember 4; Volume (5). Tersedia pada: http://iosrjournals.org.

Khusaini M. 2006. Ekonomi Publik, Desentralisasi Fiskal dan Pembangunan Daerah. Malang (ID): UB Press.

Kuncoro M. 2004. Otonomi \& Pembangunan Daerah. Jakarta (ID): Penerbit Erlangga.

Melliana A, Zain I. 2013. Analisis Statistika Faktor yang Mempengaruhi Indeks Pembangunan Manusia di Kabupaten/Kota Provinsi Jawa Timur dengan Menggunankan Regresi Panel. Jurnal Sains dan Seni POMITS. Terbit 2013 [Internet]. Diunduh 2015 November 5; Vol. (2); No.2. Tersedia pada: http://ejurnal.its.ac.id.

Oriakhi DE, Ameh G. 2014. Government Expenditure and The Development of The Education Sector in Nigeria: An Evaluation. Review of Public Administration and management. Issued July 2014 [Internet]. Diunduh 2016 Januari 5; Vol(3); No.5. Tersedia pada: http://arabianjbmr.com.

Sanggelorang SMM, Rumate VA, Siwu HF. 2015. Pengaruh Pengeluaran Pemerintah di Sektor Pendidikan dan Kesehatan terhadap Indeks Pembangunan Manusia di Sulawesi Utara. Jurnal Berkala Ilmiah Efisiensi. Terbit Juli 2015 [Internet]. Diunduh 2016 Februari 14; Vol.(15); No.02. Tersedia pada: http://ejournal.unsrat.ac.id.

Sofilda E, Nurhayati, Hamzah M.Z. 2015. Government Spending Contributions on per Capita Income and its Effect toward the Human Development Index (Comparative Study between Western Indonesia and Central \& East Indonesia). Journal of Social and Development Sciences. Issued September 2015 [Internet]. Diunduh 2015 Desember 4; Vol.(6); No.3. Tersedia pada: http://ifrnd.org.

Sumas S. 2012. Dampak Kebijakan Fiskal Sektor Pendidikan Dan Sektor Kesehatan Terhadap Indeks Pembangunan Manusia Di Indonesia [disertasi]. Bogor (ID): Institut Pertanian Bogor.

Yanuarta H. 2009. Strategi Alokasi Anggaran Pembangunan Dalam Rangka Peningkatan Indeks Pembangunan Manusia Di Kabupaten Lampung Barat [tesis]. Bogor (ID): Institut Pertanian Bogor. 